\title{
AUSTRALIAN ANTHROPOLOGY: FOUNDATIONS AND FUNDING
}

\author{
D.J. Mulvaney
}

As its inaugural President, in 1890, A.W. Howitt welcomed the establishment of an Anthropology Section within colonial Victoria's Royal Society. That tiny but optimistic group was destined to have its stability destroyed by the great economic depression of the $1890^{\prime}$ 's, but in 1890 it constituted a unique combination of talent, because three of Australia's most significant anthropological pioneers held membership. In addition to public servant Howitt (1830-1908), there was his missionary collaborator, Lorimer Fison (1832-1907), while the youthful biology professor, Baldwin Spencer (1860-1929), was both secretary and editor of the Royal Society of Victoria. Their interests and objectives epitomise Australian anthropology, at least until the creation of that continent's first academic department of Anthropology, at Sydney in 1926.

\section{The evolutionary paradigm and Aboriginal people}

Howitt solemnly instructed the membership, ${ }^{1}$ that 'it behoves us ... to set earnestly to work to record all that can be learned as to customs and beliefs, the arts of peace and war, of probably the most primitive race now existing of mankind'. Howitt neither questioned the moral obligation, incumbent upon amateurs and scientists alike, to undertake this empirical assemblage of ethnographic data, nor its urgency. He was stimulated by the social evolutionary paradigm known today as Social Darwinism and excited by the assumed potential of Aboriginal society to act as a storehouse of fossil customs and primeval survivals, ${ }^{2}$ which would supply vital clues concerning 'the probable origin and development of social institutions'. These people supplied the prototype of hunter-gatherer society, in every aspect, economic, social and physical, "the iconic people of anthropology', as Elvi Whittaker termed them at the Workshop. Time was short. Howitt already had predicted the virtual extinction of the Aboriginal race across the continent within a generation. ${ }^{3}$ That same year, a science congress was consoled by James Barnard, ${ }^{4}$ that the passing of the Aboriginal race was inevitable and in the ultimate interests of future humanity: 'It has become an axiom that, following the law of evolution and the survival of the fittest, the inferior races of mankind must give place to the highest type of man'.

Regrettably for the future of anthropology, neither Howitt nor his colleagues pondered the ethical issues associated with their data amassing mission, as they and their successors pried or cajoled their way into the secret life of their informants. Even though they were persons of integrity and had good rapport with their (male) English speaking informants,

Emeritus Professor John Mulvaney is Secretary, Australian Academy of the Humanities.

This paper was delivered in July 1990, at the Canada-Australia Workshop on Science and Technology, Victoria, British Columbia. It was supported by the Social Sciences and Humanities Research Council of Canada, and organised by Dr Richard A. Jarrell, Department of Science Studies, York University, Ontario, and by Professor Roy McLeod, Department of History, University of Sydney.

Howitt 1891, p. 22.

ibid, p. 16.

Howitt 1889, p. 96.

Barnard 1890, p. 597. 
they assumed a scientific 'objectivity' which justified generalising their scraps of information into comprehensive general propositions. Social theory so dominated their collecting, that usually the names of their informants were omitted, while they showed little concern for the social problems of fringe dwelling detribalised people. Their concern was to record those institutions, customs or artefacts which they assumed were authentic survivals of traditional society.

One theme of this paper concerns the consequences of this emphasis upon the social evolutionary model. In a recent lecture, Nicolas Peterson ${ }^{5}$ questions the extent to which past governments utilised anthropological expertise, and notes the infrequency with which anthropologists believed that Aboriginal society offered opportunities for applied anthropology, rather than emphasising the urgency of salvage. Peterson correctly concludes that the evolutionary paradigm led researchers into theoretical rather than practical issues. It was the functionalist school of anthropology, later introduced by A.R. Radcliffe-Brown at Sydney, which concentrated upon horticultural/ agricultural societies, such as New Guinea. Such societies were more amenable to indirect rule and therefore were thought to possess greater relevance to functionalist theory than the less hierarchical Australian societies, which were neglected by most fieldworkers.

Even so, these early ethnographers were the most expert authorities available, their status and contacts resulted in their opinions being known, even if they were not consulted officially. As examples, Howitt served on a Victorian Royal Commission on Aborigines; Spencer was appointed by the Commonwealth government to advise it on Northern Territory native policy; W.E. Roth, a medical officer and ethnographer of note, was Queensland's Protector of Aborigines and headed a Western Australian Royal Commission. Whatever form these influences took, the consequences for Aboriginal people often proved tragic. Their publications or contacts indirectly served to underpin popular prejudices and misconceptions. Their theories justified laws and behaviour which effectively denied human dignity and civil rights, while ignoring the individual as the essential human social unit. This identification of anthropologists with official bureaucracy in the past is largely responsible for the ambivalent place of anthropologists in contemporary Aboriginal society. Unfortunately, also, archaeologists are popularly associated with evolutionary theory, so they are also subject to suspicion or antagonism from revitalised Aboriginality, whose philosophical basis, the Dreaming, is creationist, a concept bolstered today by Fundamentalist Christian influences.

Howitt's exhortation to ethnographic research also failed to mention a paramount consideration of modern research, that is the manner of its funding. Probably this matter was so obvious to his audience that it was irrelevant, because funding was not always regarded as the lifeblood of Australian research. Self-help was then the customary order. No publicly funded research granting schemes existed until well into the twentieth century, and although the four existing universities were state enterprises, financial provisions for research were minimal. As for anthropology, it was not taught anywhere under any of its manifestations, until a Chair of Anthropology was established at Sydney university in 1926. Although Australian benefactors drew their wealth chiefly from the pastoral exploitation of Aboriginal lands, they seldom endowed any academic enterprises, while anthropological needs were ignored. The changing nature of support for anthropological research is another theme examined later.

At the time Howitt urged the investigation of Aboriginal society, few would have questioned the dismissive assessment of Baldwin Spencer's friend and colleague, Edward

5

Peterson 1990. 


\section{AUSTRALIAN ANTHROPOLOGY}

Jenks. Jenks, an academic lawyer, published his popular A History of the Australasian Colonies in 1895. 'The Aborigines ...', he wrote, ${ }^{6}$ 'have had no influence over Australian history. Absolutely barbarous and unskilled in the arts of life, dragging out ... a wretched and precarious existence even before the arrival of European settlers, they could offer no resistance to the invaders, and they have, in fact, been entirely ignored (except as objects of charity or aversion) in the settlement of the country'. Only in the past few years have most European Australians recognised the invalidity of such assumptions concerning Aboriginal society.

\section{Prejudice and dogma in anthropological history}

The opinions typified by Jenks remained orthodox for decades and they still have their cynical adherents. Aborigines remained the passive recipients of 'research' based upon preconceived philosophical or evolutionary notions. The establishment of anthropology as a discipline must be assessed within this ideological context. There is little point in recapitulating much of the evidence here, because it has been expounded elsewhere. ${ }^{7}$ Other recent reappraisals include papers by Peterson, ${ }^{8}$ Jones $^{9}$ and the detailed biographies of A.P. Elkin $^{10}$ and Sir Baldwin Spencer. ${ }^{11}$

Before selecting some case studies which reflect the development of the discipline in Australia, it is necessary to provide some background as to why it is that the present nonAboriginal Australian population faces moral, political and legal dilemmas in its relationship to Aboriginal Australians. For this situation, earlier 'experts' share much of the responsibility and it is an essential aspect of the growth and standing of anthropology. This is an assessment with the wisdom of hindsight. It is only fair to observe that many ethnographers were humanitarians in spirit and were well in advance of their contemporaries in their racial attitudes and their integrity.

The crucial message conveyed by recent archaeological discoveries and the existing close collaboration between communities and anthropologists, concerns the essentially human values which characterised Aboriginal society from ancestral to contemporary generations. The varied burial rituals and other ceremonial activities inferred from the evidence, the antiquity and great stylistic variations in art and the concern for spiritual life and intimate connections with the land, all demonstrate that the spiritual and social life which characterised Aboriginal societies in 1788, possessed immense time depth. Yet early colonists brought a contrasting package of perceptions to bear on Aboriginal society. They deemed it impossible for Aborigines to possess any creative imagination, spirituality or humanitarian attitudes. As significant and influential interpretations of Aboriginal life, it is appropriate to commence with two early explorers, (Sir) George Grey and E.J. Eyre, men who wrote informatively and sympathetically about Aboriginal society.

George Grey discovered the Wandjina rock art form in the Kimberleys in 1838 . We know today that this tradition of huge, mouthless beings both unites the present generation with Dreaming creation time and identifies it with the local landscape in a deeply meaningful manner. In his published journal, Grey described the paintings objectively

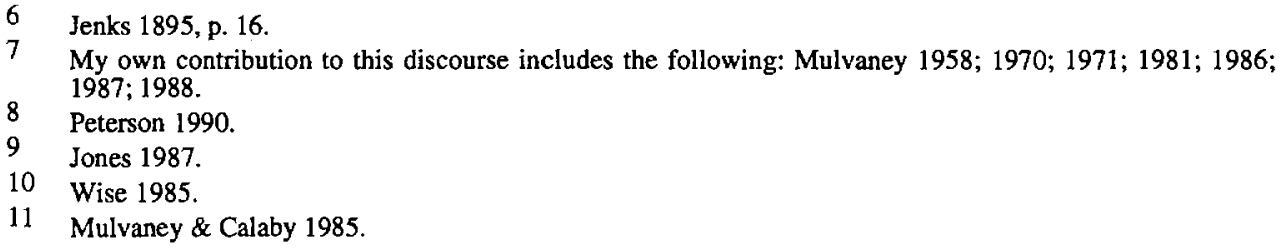

11 Mulvaney \& Calaby 1985. 
enough. He noted ${ }^{12}$ that markings around one figure resembled 'written characters or some ornament' and that they wore 'a sort of dress' (actually ceremonial body painting). He went further in his concluding remarks:

But the art and skill with which some of the figures are drawn, and the great effect which has been produced by such simple means, renders it most probable that the painting must have been executed with the intention of exercising an influence upon the fears and superstitious feelings of the ignorant and barbarous natives...

Grey was more specific in his report to the Colonial Office, parts of which were published. ${ }^{13}$ He assumed the art to be the work of a 'race of Asiatic origin,' and so set a speculative pattern. According to the taste or prejudices of later authors, these foreign artists and their 'script' were Greek, Egyptian, Assyrian, Indian, Malay, and in the ultimate Von Daniken lunacy, men from outer space. Obviously, this is a form of racism. As Aborigines were rude and elementary artists, it is implied, these paintings were beyond their creative capabilities. This denigration of Aboriginal art had a remarkably durable role in conditioning other Australians to overlook the vigour and the symbolism of Aboriginal art in its many manifestations. Aboriginal art has appeared in art galleries only during the past two decades.

After later residence at Albany and then as South Australian governor, Grey became more familiar with and sympathetic to Aboriginal culture. His journals are an important source for language, attempts to infer rules of kinship and contain the first reference to the existence of totemism. In correctly inferring the importance of law in Aboriginal society, he formulated an interpretation which deprived that society of any innovative changes, denying any creative role or freedom to individuals. Presumably the rigid world which Grey described was the antithesis to his concept of British democracy ('civilisation'). Because so many later colonists echoed such views, they merit quotation: ${ }^{14}$

But to believe that man in a savage state is endowed with freedom either of thought or action is erroneous in the highest degree. He is in reality subjected to complex laws, which not only deprive him of all free agency of thought, but, at the same time allowing no scope whatever for the development of intellect, benevolence, or any other great moral qualification, that necessarily bind him down in a hopeless state of barbarism, from which it is impossible for man to emerge ...

Divine Providence, Grey believed, ${ }^{15}$ had placed Aborigines in Australia, and because they were in the thrall of barbaric custom and ignorance, they 'must have been instructed how to provide for their wants, how to form weapons ... to capture animals ...' A divine 'Infinite wisdom' deliberately peopled the continent with this unchanging lifeway, 'until the race ... (came) into contact with a civilised community, whose presence might exercise a new influence under which the ancient system would expire or be swept away'.

Such an anticipation of the White Man's Burden clearly empowered European settlers under Divine sanction to subdue the earth, to dispossess the inferior occupants of the land. These sentiments, it should be noted, were those of a colonial governor, writing two decades before the Darwinian 'survival of the fittest' became a catch-cry. Grey's explorer contemporary, Edward John Eyre, also recorded important data about Aboriginal society. Like Grey, however, his model of spirituality was moulded by the precepts of Victorian

12

13

14

15

Grey 1841,1, p. 214, p. 263.

Grey 1838 , pp. $459-60$.

Grey 1841, II, p. 217.

ibid, p. 224. 


\section{AUSTRALIAN ANTHROPOLOGY}

Christianity. The Aborigines, Eyre concluded, 16 'have no religious belief or ceremonies', despite the fact that he described ceremonial activities at considerable length- 'all generally so absurd, so vague, unsatisfactory and contradictory, that it is impossible ... to say ... whether they have any independent beliefs at all'. These dismissive conclusions on Aboriginal intellectual life were offered by two of the most observant Europeans to describe indigenous society. It is significant that such an ideological perspective left no place for imagination or individuality. As they wrote before Darwinian evolutionary theory became popularised, it is not surprising that Aboriginal culture later was subjected to even worse misunderstanding by exponents of social evolution. Social Darwinists converted Australia into the exemplar of primitive society on the lowest rung of evolutionary progress, as human and institutional survivals since before Adam.

C. Staniland Wake was a typical early overseas social theorist. In 1872 , he drew upon sources such as those quoted above. 'They represent the childhood of humanity', Wake concluded of the Australians. ${ }^{17}$ 'On all questions of morality, and in matters connected with the emotional nature, mere children'; their art 'may be classed with the productions of children'.

From England Wake corresponded with the founding fathers of Australian anthropology, Lorimer Fison and A.W. Howitt. In their turn, they drew inspiration from the great American social theorist, Lewis Henry Morgan. Morgan urged them to use Aboriginal ethnography as a social laboratory, not because of any interest in their culture as individual people, but as a scientific guide to the origin of human institutions. ${ }^{18}$

'You are several strata below barbarism into savagism', Morgan wrote in 1872 , 'and nearer to the primitive condition of man than any other investigator. You have in their institutions of consanguinity, marriage and tribal organisation, far reaching and intelligent guides, not only to their present, but also to their past, condition. When all the facts are ascertained ... we shall recover the thread of man's progress from the first to the last clearly and accurately defined ...'

In this global network of kindred social Darwinist theorists, Howitt and Fison also worked closely with the English social theorist, Edward Tylor, ${ }^{19}$ who considered that the Tasmanians were the living 'representatives of Palaeolithic Man'; 'just as mollusca of species first appearing far back in the earlier formations may continue to live and thrive in modern seas'.

Alfred Howitt ranks as one of Australia's most versatile and engaging intellects. It is significant, however, that although he wrote a major anthropological book on Aboriginal society, his The Native Tribes of South-East Australia (1904) deals with a society already deemed by him as past. He ignored current problems of contact and social disruption, and even omitted the names of his individual informants, despite the fact that he knew many of them well. This 'scientific' detachment probably explains his attitude as a member of the 1877 Victorian Royal Commission on the Aborigines, where present problems were the issue under investigation.

The report of that Royal Commission contained some sound observations on the nature of Aboriginal society, including the significant admission, ${ }^{20}$ that 'the care of the natives who have been dispossessed of their inheritance by colonisation is a sacred

16 Eyre 1845 , II, p. 355.

17 Wake 1872 , p. 83 , p. 79 , p. 75 for quotations.

18 Mulvaney 1971, p. 295.

19 Tylor 1893, p. 150.

20 Victoria, Royal Commission on the Aborigines 1877, p. xii, p. xvi. 
obligation ... their degradation was no less shameful to humanity than appalling in the sight of Christian men'.

Moral principles stated, however, the Commission recommended what is seen today as a heavy-handed and misguided paternalism. There is no evidence that Howitt disagreed with its recommendations, which included the establishment of centralised government stations, or that he rejected its unfortunate anthropological interpretation. This stated firmly, that 'it may be supposed that attachments to localities and hereditary tribal enmities, would militate against any efforts to bring them in: but the existing local attachments are ... of recent origin; on the breaking up of the tribes consequent upon the breaking up of their territories and on the decrease numerically ... the love of the land on which they were born, and which they considered therefore as theirs, became lessened. The tribes, as tribes, no longer exist, and the individuals yet remaining have formed associations which are not necessarily connected with former tribal boundaries ...'

This rationalisation for further dispossession from Aboriginal lands must have appealed to white settlers. It contrasts with the agreed decision of an earlier Victorian Legislative Council Select Committee on the Aborigines. ${ }^{21}$ In 1859, that committee accepted the advice of the Chief Protector, William Thomas, that central stations were impractical for humanitarian reasons. 'The blacks would not leave their own hunting grounds, and would pine away at once if removed from them. The various tribes would never agree ... consequently the idea of settling them together was reluctantly abandoned'.

Baldwin Spencer, a biologist and director of the National Museum of Victoria, achieved an international reputation for his anthropological field work around the turn of the century. Spencer, who had been taught by Tylor and was befriended by Howitt, typified the intellectual stance of the paradigm of evolutionary social theory. It served to divorce living informants as individuals from abstract social, but assumed scientific principles: As the most influential adviser to government of his generation, he was sent to Darwin in 1912, to formulate policy for the Commonwealth government. He advocated a stern paternalist policy based upon social Darwinist concepts.

Assessed from the modern perspective, it is regrettable that even his most constructive recommendation, the establishment of major Aboriginal reserves, was conditioned partly by his biologically determined thesis that the Aboriginal race was destined to become extinct, and therefore humanitarian principles coincided with the expediency of studying them while there was time. ${ }^{22}$ The priority of science was given public expression at the 1913 Australasian Association for the Advancement of Science (AAAS) meeting in a resolution, 23 'That in view of the rapid decadence and disappearance of the Australian aborigines, it is urgent that, in the interests of science further records and collections, illustrative of the beliefs, customs, and manner of life ... should be made for public preservation'.

Spencer's formal scientific training overshadowed his personal humanitarianism. In his 1901 museum handbook, for example, Spencer deplored the passing of the Tasmanians, chiefly it seems, because of their scientific potential: ${ }^{24}$

They were, in fact, living representatives of palaeolithic man, lower in the scale of cultures than any human beings now upon earth. It is a matter for the

21 Victoria, Parliament, Legislative Council 1859, p. v.

22 Spencer 1913.

23 Resolutions of Section F, Australasian Association for the Advancement of Science Reports of Meetings, 1913, vol. 14, p. 453.

24 Spencer 1901, p. 8, p. 12. 


\section{AUSTRALIAN ANTHROPOLOGY}

deepest regret that they were allowed to become extinct without our gaining anything but the most meagre information ...

As for the mainlanders, they 'may be regarded as a relic of the early childhood of mankind left stranded in a part of the world where he has, without the impetus derived from competition, remained in a low condition of savagery'. Capitalism and progress therefore went together. As James Frazer observed of Spencer's findings: ${ }^{25}$ 'In the struggle for existence progress depends mainly on competition; the more numerous the competitors, the fiercer is the competition, and the more rapid consequently is evolution'.

This intellectual tradition largely continued in the person of A.R. Radcliffe-Brown, the first holder of an anthropology chair at an Australian university and one of the most influential anthropologists this century has produced. Radcliffe-Brown came to Sydney in 1926, but had previous field experience in Western Australia. Radcliffe-Brown worked amongst the inmates of the Lock Hospital for venereal diseases, on Bernier Island in 1910. Amongst its miserable 'living dead' (as Daisy Bates termed those incarcerated people), Radcliffe-Brown collected genealogies and checked kinship systems, with scientific zeal and objectivity ${ }^{26}$ This interlude was surely an instance of Radcliffe-Brown's reported model scientific anthropologist: 27

He treats the human native as the chemist does his substance ... if he admits human sympathies and interests, he impairs the validity of his work. He then becomes a human being. The ideal anthropologist must not judge "this is good, or this is bad", he must only record and deduce.

Radcliffe-Brown proved equally detached when he delivered an ANZAAS presidential lecture in 1930, extolling the virtues of Applied Anthropology and the need to formulate general laws of social change and social control. ${ }^{28}$ Significantly, the purpose of this social anthropological research as he expounded it, was to improve administration in Papua New Guinea. His discussion of Australian research needs was restricted to human biology. Evidently, he saw no scope for the application of social anthropological concepts to Aboriginal administration:

Australia, by its possession, in the aborigines, of a highly specialised variety of our species affords an opportunity for very important investigations in the field of Human Biology, an opportunity, however, which must be seized very soon, since, with the rapid disappearance of the race, in a few years it will have gone.

\section{White Australia}

During the early decades of this century European Australians worried over two racial issues which they considered basic to the fabric of society. The first concerned the maintenance of a White Australia, the other the problem of the so-called half-caste population. The roots of both these racial obsessions had diverse origins in the Australian psyche, but they were bolstered and given academic respectability by scientists with social evolutionary preconceptions. Eugenics, social engineering, promised to improve the racial stock through selective breeding of the population within Australia, while strict immigration laws ensured the continuing purity of the White gene pool. Radcliffe-Brown sensibly thought that it was 'premature' to create an applied science institute of Eugenics,

25 Frazer 1899 , p. 281.

26 Mulvaney 1989 a, pp. 183-94

27 Warner et al 1928 , pp. 67-9.

28 Radcliffe-Brown 1930, p. 268. 
until greater knowledge was obtained of the principles of heredity and variation. ${ }^{29}$ However, he conceded that it was desirable "to improve the average quality of the human stock, to breed finer men and women, to eliminate as far as possible the feeble-minded and degenerate'. When giving evidence to a 1933 Western Australian Royal Commission on the treatment of Aborigines, a medical witness expressed matters more bluntly: 30

I wish to speak of the half-caste and the breeding out of the half-caste, the

black man, whose presence irritates us ... and who is now in addition a standing menace to our dreams of a white Australia.

Significantly, the thirties ushered in the racial evils of Hitlerite Germany, with which these sentiments were in accord. Australia was actually at war with Germany, when the Western Australian Commissioner of Native Affairs praised the use of "corrective discipline' for Aborigines, ${ }^{31}$ which was not a policy employed 'elsewhere, except in Germany, I doubt whether methods such as these have been adopted in dealing with the forced labour of natives ...'

In 1937, the state and commonwealth governments adopted the Policy of Absorption, ${ }^{32}$ believing "that the destiny of the natives of Aboriginal origin, but not of the fullblood, lies in their ultimate absorption by the people of the Commonwealth and it therefore recommends that all efforts be directed to that end'. The consequence was the assimilation policy of transforming 'them' to 'us'. One of Australia's major moral and social problems today, is inherited from the consequences of this denial of human rights, when children and parents are separated 'for their country's good'. The policy was espoused, amongst others, by Radcliffe-Brown's influential successor in the Sydney Chair, A.P. Elkin. 33

Assimilation had been supported previously by Baldwin Spencer, who advised the Commonwealth government: ${ }^{34}$ 'The aboriginal', he informed parliament, 'is a very curious mixture; mentally, about the level of a child who has little control over his feelings ... He has no sense of responsibility and, except in rare cases, no initiative'. As for half-castes, 'the mother is of very low intellectual grade, while the father most often belongs to the coarser and more unrefined members of higher races'. Anticipating Radcliffe-Brown and Elkin, Spencer saw the solution in the removal of such children from their aboriginal mothers "even though it may seem cruel to separate the mother and child, it is better to do so ...'

In the light of such evidence for cultural bias, it is understandable that Aboriginal people feel antagonistic to, or suspicious of, anthropologists. This applies equally to archaeologists, whose late arrival on the Australian scene means they were not involved in those previous ideologies or activities. However, they have been labelled together with an earlier generation of 'diggers,' whom archaeologists disown. These were the biological scientists, vainly optimistic and racially biased, who equated non-whites with evolutionary primitiveness, and who promoted eugenics and comparative racial studies, while throughout the first half of this century they removed burials to museums in their hundreds. The rub for archaeologists like the author is that, in reference to ancient burials, they are aware that those remains are now important for totally different reasons. The chief of these is the

ibid.

Jacobs 1986 , p. 19.

Hall 1989, p. 24.

Jacobs 1986 , p. 15.

Mulvaney 1989a, pp. 199-205.

Spencer 1913, p. 14, p. 21. 


\section{AUSTRALIAN ANTHROPOLOGY}

cultural and genetic data encoded in those burial practices and bones, which is of future deep significance to Aboriginal people themselves and scholars. 35

This selective survey of the perceptions of earlier prominent authorities in the white community indicates that even though they acted in good faith within their ambient culture, they provided intellectual justification for policies which today are recognised to be terribly wrong, morally, socially and legally. Aboriginal critics accuse 'anthropologists' of justifying the dispossession of their people, and what they term as 'genocide'. Although these accusations are invalid today, even the most sympathetic pro-land rights 'anthropologist' cannot refute them as applied to the past. Understandably, to say 'sorry, anthropologists were wrong', may not satisfy Aboriginal critics, yet it is best to admit reality and then to seek appropriate future solutions. It is worth reflecting that the anthropology discipline was established when 'science' held sway in a remarkably subjective ambience. Even its most enlightened Australian practitioners subscribed to such notions as the mental inferiority of the Australian race, the need for firm interventionist control of all Aboriginal people, and their imminent (and scientifically immutable) racial extinction. They also adhered firmly to the dogma of White Australia. It seems paradoxical today, when this awful intellectual inheritance is the greatest conscience stirrer and inhibitor of the discipline.

Paradoxical indeed. While Aboriginal society and its material conditions and living standards worsened, social evolutionists salvaged away, deducing survivals from the survivors and contributing substantially to intellectual models erected overseas by historians and sociologists of ideas. The impact of Australian data began in the 1870's, when Howitt and Fison were transmitted via Lewis Henry into the schema by Friedrich Engels, The Origin of the Family. Fison and Howitt, Spencer and Gillen, became familiar footnotes in conflicting theories and constructs of enormous importance in the western world during the early decades of this century. Such contributions to social theory included works by Wake, ${ }^{36}$ Crawley, ${ }^{37}$ Andrew Lang, ${ }^{38}$ Thomas, ${ }^{39}$ Van Gennep, 40 Westermarck, ${ }^{41}$ Marrett, ${ }^{42}$ Hartland, ${ }^{43}$ Durkheim $^{44}$ and Freud. ${ }^{45}$ There were strong ideological links, it seems, between Sir James Frazer's Golden Bough and Australian flora; the pre-fieldwork Malinowski quarried a mass of Australia ethnography. ${ }^{46}$ Theories of the origin and symbolism of European cave art, propounded by $S$. Reinach and $H$. Breuil originated in the pages of Spencer and Gillen. ${ }^{47}$ It is ironic, therefore, that none of the Australian data utilised in these diverse schema were collected by professional anthropologists, while many of the ideas advanced by those celebrities who adopted them, were obsolete before any anthropological post became established in Australia. It also is

Mulvaney $1989 \mathrm{~b}$.

Wake 1889.

Crawley 1902.

Lang 1903; 1905.

Thomas 1906.

Van Gennep 1906; 1909.

Westermarck 1906.

Marett 1909.

Hartland 1909.

Durkheim 1912.

Freud 1913.

Malinowski 1913.

Mulvaney 1981, p. 62. 
highly relevant in retrospect, that the Aboriginal people were mere ciphers in those grand evolutionary designs.

\section{Intellectual networks on the periphery}

Although an anthropological division had been established in 1888 , at the inaugural congress of the Australasian Association for the Advancement of Science, anthropology remained the preserve of a few amateurs, particularly public servants, clergymen and pastoralists. ${ }^{48}$ Such busy enthusiasts were remarkably dedicated, usually working in geographic isolation, far removed from their intellectual peers, in our ambient cultural environment of indifference or racial contempt. Often, their sole reward was praise from some distant great man whom they never met.

Their perseverance in the face of physical and intellectual adversity is a cogent argument for applying the model-patron/client: centre/periphery-to the growth of Australian anthropology. Well documented intellectual relationships, such as those between Lorimer Fison and Lewis Henry Morgan, Howitt and E.B. Tylor, R.H. Mathews and Mrs Langloh Parker with Andrew Lang, Spencer and Gillen with Sir James Frazer, proved rewarding motivational and directional lodestars for the colonial beneficiaries of metropolitan patronage, praise and publicity. 49

When applied to the local situation, however, this model's imperial centrality and simplicity conceals the extent to which the clients were themselves initiators of field methods, or devised innovative concepts, which did not slavishly imitate their patron's pattern. ${ }^{50}$ The network of contacts established around the continent between 'clients' proved equally important. Just as Howitt drew inspiration from overseas mentors, for example, so he encouraged local linkages by producing and distributing at least eight types of questionnaire between 1874 and 1885 . Such questionnaires were based originally upon the one circulated by L.H. Morgan, which reached Fison in Fiji in 1869. However, Fison and Howitt modified that form in 1874, and thereafter Howitt devised questionnaires which were ambitious variants of their original adaptation, together with others on astronomy, body marking, ceremonial painting and song. ${ }^{51}$ Alternative questionnaires were distributed by other ethnographers during this same period. These included E.M. Curr, ${ }^{52}$ the South Australian missionary, George Taplin, ${ }^{53}$ and R. Brough Smyth, ${ }^{54}$ to whose volumes Howitt and Fison both contributed, although they subsequently criticised the standard of his compilation. ${ }^{55}$

These prominent postal ethnographers became patrons to their own far-flung networks, occasionally obtaining publication space for their clients from their own metropolitan mentors. Such mutually congratulatory networks regrettably competed with other systems, sometimes their central directors being accused of 'pirating' opposition questionnaire techniques or data.

This intense sense of rivalry clouded the wisdom of clergymen, public servants and academics alike, ironically at the very period when urgent collaboration in the supreme interests of science was invoked. Jealousy, a desire to monopolise knowledge of a region,

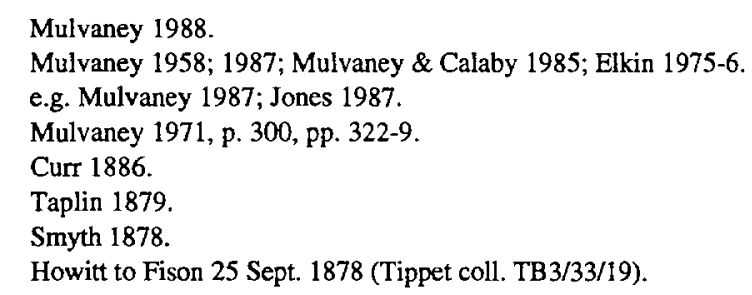




\section{AUSTRALIAN ANTHROPOLOGY}

or fame in being the first to communicate it, soured this otherwise major voluntary research effort. Such petty colonial attitudes carried over into Federation and characterised some later professional anthropologists, who were notorious for their territorial dominance, or for impeding access to 'their' people or State. This petty behaviour has been documented in relations between A.P. Elkin, the Sydney anthropologist and South Australian researchers. ${ }^{56}$

The initial stage of systematic research consequently was marred by self-interest. The otherwise judicial Howitt, for example, ignored questions about ethnography from James Dawson, who was compiling his The Australian Aborigines (1881). After Howitt informed Fison of this request, Fison criticised 'your Mr Dawson and his cool request'. Indeed, the reverend gentleman termed such scholars 'literally cannibals'. Howitt also failed to respond when an American ethnographer sought details about gesture language, 'because I can see a most valuable chapter' on that subject himself. Four months later he had devised and distributed a questionnaire on gesture language and had received a completed form from Central Australia. ${ }^{57}$ E.M. Curr, compiler of the four volumes, The Australian Race (1886), cordially supplied Howitt with information in 1874 , whereas he was posting circulars himself by 1879 . Rivalry became mutually intense. Howitt reported on an occasion when he met Curr in Melbourne by chance-He 'did not get much out of me-I did not get much out of him'. It was due largely to their fear that Curr would 'scoop' their discoveries, that Howitt and Fison hurried publication of Kamileroi and Kurnai (1880). This was done at considerable financial cost, and in full knowledge that their mentor, L.H. Morgan, had not recovered his costs on Ancient Society, even though 1000 copies had sold. ${ }^{58}$

The missionary, Reverend George Taplin, posed different problems. He was an early collaborator, returning completed questionnaires to Fison in 1872 and 1873 . When Taplin published his own book, Folklore, Manners, Customs and Languages of the South Australian Aborigines in 1879, he made no reference to Fison initiating him into the postal questionnaire technique. Neither Fison nor Howitt was mentioned, but Taplin highlighted his later contacts with the South African ethnographer, W.H. Bleek. ${ }^{59}$ As Taplin first wrote to Bleek on 29 January 1874, it suggests that Fison and Howitt had some cause for pained accusations, that Taplin appropriated their questionnaire technique and ideas without acknowledgement. ${ }^{60}$

The most violent character assassination during those forthright times involved Baldwin Spencer. He cried plagiarism, when evidence supplied by R.H. Mathews was used by Andrew Lang as a stick to beat James Frazer's theories via Spencer and Gillen. Spencer wrote angrily to Frazer, effectively expunging Mathews from the scholarly lists. He claimed support for his accusations from Howitt, Fison and W.E. Roth, although the justice of such blackballing is questionable. ${ }^{61}$ Elkin championed the cause of Mathews. ${ }^{62}$ Spencer also dismissed as 'rubbish', the theological interpretation of Aranda religion by the

56 Mulvaney 1988.

57 Dawson: Fison to Howitt 24 Aug 1877 (Fison papers NLA MS 7080); Howitt to Fison 21 Apr 1877, 21 Mar 1880 (Tippett coll TB3/33/13). American: Howitt to Fison 1 Feb, 27 June 1881 (Tippett Coll).

58 Howitt to Fison 10 Apr 1880 (Tippet coll); Fison to Howitt 22 July, 25 Oct 1879 (Fison papers NLA MS 7080); Mulvaney 1971, p. 297. Morgan: Fison to Howitt 14 May 1880 (NLA MS 7080).

59 Bleek 1874.

60 Taplin to Fison 4 Oet 1872, 1 Dec 1873, Fison to Taplin 5 Mar 1875 (Fison papers NLA MS 7080); Howitt to Fison 6 Oct 1879 (Tippett coll); Mulvaney 1971, p. 300, p. 342; Bleek 1874, p. 132; Taplin 1879, p. 1.

61 Mulvaney and Calaby 1985, p. 215; Howitt to Fison 19 Apr 1899 (Tippett coll).

62 Elkin 1975-6. 
Lutheran missionary Carl Strehlow. ${ }^{63}$ His own understanding of the nature of Aboriginal ceremonial life was equally in error.

\section{Artefact collection and distribution}

Aboriginal artefacts had been collected as curios or exemplars of savage life since 1788 . The postal ethnographers went further, in collecting material objects chiefly to illustrate the technology and intellectual level of Aboriginal culture. While they retained items in their private cabinets or donated them to regional or colonial (later state) museums, many objects were sent to their overseas patrons. Tylor even requested specific items from Howitt. 64

Not surprisingly, their typological arrangement of exhibits 'confirmed' the 'primitive' characteristics of Australian technology, by being placed at the beginning of any linear sequence. The classic statement of evolutionary material typology was presented by Lt. General Pitt-Rivers, although Spencer echoed him in his 1901 Guide to the Australian Ethnographical Collection of the National Museum of Victoria. All Aboriginal weapons, Pitt-Rivers stated: 65

assimilate the forms of nature; all their wooden weapons are constructed on the grain of the wood, and consequently their curves are the curves of the branches ... In every instance in which I have attempted to arrange my collection in sequence, so as to trace the higher forms from natural forms, the weapons of the Australians have found their place lowest in the scale, because they assimilate most closely to the natural forms.

During that period of minimal museum funding, curators used local artefacts as a form of barter currency to exchange for ethnographic items from other cultures. In this way Australian material culture became widely dispersed in European and American museums. ${ }^{66}$ Baldwin Spencer freely dispersed his museum's collection (largely accumulated through his initiatives) in the cause of comparative ethnography. He sent at least 153 specimens to Leningrad in 1908, in exchange for a Samoyed sledge and accoutrements. ${ }^{67}$

Missionaries on the Australian periphery also initiated networks which supplied information and artefacts to their European birthplaces or religious centres. German Lutheran missions, in particular, played a major role in supplying institutions in the Fatherland with exhibits. Although many collections were destroyed during wartime bombing, surviving collections are important because of their representativeness and the early date at which many were acquired. The meticulously documented records of these Lutheran missionaries constitute a major anthropological resource. Pastor Carl Strehlow's Die Aranda und Loritja-Stamme, six publications between 1908 and 1921, is a work based upon a deeper linguistic knowledge than that possessed by his contemporaries, Spencer and Gillen. Fortunately for Australian culture, some Lutheran missionaries also supplied the South Australian Museum with unique material. The most significant of these was J.G. Reuther (1861-1914), based at Killalpaninna, east of Lake Eyre. ${ }^{68}$

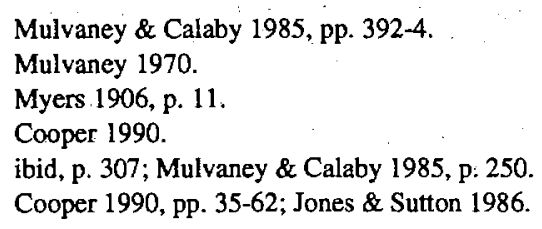




\section{Research funding before 1914}

Although there were no public funds dedicated for anthropological research during the era before the University of Sydney department opened in 1926, there were many expedients which assisted that cause. 69 One related to the use of government printing offices to facilitate publication. Possibly the earliest official assistance was engineered by R. Brough Smyth, secretary to the Victorian Board for the Protection of the Aborigines. He collated material for his Aborigines of Victoria, printed in 1878 by the Government Printer, as also was E.M. Curr's The Aboriginal Race (1886). Smyth authorised the printing of the first series of Howitt and Fison questionnaires in 1874, although postage fees were a burden on its authors, as was the expense of printing Kamileroi and Kurnai, for which they shared the cost of publishing 550 copies. $^{70}$

Until the premature abolition of the Geological Survey of Victoria in 1869, Brough Smyth also served as its secretary. The Victoria Survey achieved notable success under the direction of A.R.C. Selwyn, later to achieve Canadian fame. The interface between geology, archaeology and ethnography was evident in the progress reports issued by the Survey; which included references to middens and artefacts. Robert Etheridge, a staff member, later directed Sydney's Australian Museum, adding an interest in enlarging its ethnographic collections to his palaeontological expertise. Inspired by the Survey's example, A.W. Howitt published a series of detailed field studies of Gippsland geology, combining much invaluable ethnography with perceptive geology.

Both of Taplin's books were published by the South Australian government, initially after the intervention of the colonial governor, Musgrave, who was sympathetic to salvage ethnography. ${ }^{71}$ W.E. Roth's research was published officially in Queensland, while his period as that state's Chief Protector of Aborigines provided him with research opportunities. ${ }^{72}$

Howitt wished to have paid leave of absence in order to undertake a major programme of fieldwork. Both for himself and for future knowledge, it is frustrating that deaf ears were turned both in Victoria and Britain. Fison endeavoured to obtain his friend's release, when Howitt was in his prime. ${ }^{73} \mathrm{He}$ wrote to E.B. Tylor in Oxford, observing: "Anthropologists all the world over ought to combine and move heaven and earth to get Howitt released from his official duties and turned loose among the Australian aborigines. He is the man of all men to do the work if he could only get at it'.

Fison wrote from Fiji consoling Howitt, 'I wish I could help you in your Australian researches ... I can do nothing but try to set Tylor and others torturing the Colonial office to get you set apart for a year or two ...' There is no indication, however, that Tylor, Howitt's patron, acted upon Fison's suggestion. Indeed instead of receiving official encouragement, by 1885 Howitt's Minister had ordered him to desist from encouraging Aboriginal ritual ceremonies, because it incited pagan ways and caused absenteeism from rural labour. ${ }^{74}$ His later transfer from the bush to Melbourne terminated his fieldwork.

Baldwin Spencer paid all expenses involved in his own early field excursions. Even the 1901 transcontinental expedition with Gillen was largely at his expense, although The Age newspaper defrayed some costs, in return for a series of articles. He received a more positive response than Howitt from his metropolitan patrons, Frazer and Tylor. In order to facilitate

Mulvaney 1987, p. 62.

e.g. Fison to Howitt 14 May 1880 (Fison papers NLA MS 7080).

Taplin 1879, p. 1; Bleek 1874, p. 130.

Roth $1897 ; 1901-10$.

73 Fison to Tylor 27 Sept 1881; Fison to Howitt 7 Nov 1881 (Fison papers NLA MS 7080).

74 Mulvaney 1970. 
the 1901 expedition, Frazer initiated a petition to the Victorian and South Australian governments, seeking leave of absence for both Spencer and Gillen, and signed by the British academic establishment. The governments assented, granting them leave on salary and providing for their staff replacements. Spencer and Gillen also made varied and extensive use of rail and telegraph facilities, so this expedition ranks as the first major government assistance for anthropological research. Regrettably, the government assistance related more to the influence and prestige of the rich and famous, than to a desire to learn about Aboriginal society. The proud metropolitan patrons later basked in the publicity of this successful expedition, but although Spencer's financial investment was considerable, his backers provided nothing but their signatures. ${ }^{75}$

Two other systematic anthropological expeditions proved landmarks in anthropological history, but their funding was British. The Cambridge Anthropological Expedition to Torres Strait, under A.C. Hadden in 1898, set a pattern which, in its use of movie film and sound recording, Spencer and Gillen emulated. The 1910-11 Oxford and Cambridge Expedition to Western Australia was led by A.R. Brown (later Radcliffe-Brown), with a Western Australian government contribution in the person of Daisy Bates. A less celebrated and relatively unstudied series of solitary journeys was that by the German ethnographer, E. Eylmann, between 1896 and 1898 , whose corpus of artefacts is invaluable. ${ }^{76}$

The Commonwealth government assumed control of the Northern Territory from South Australia in 1910. Baldwin Spencer was appointed a Special Commissioner to the Territory and Chief Protector of the Aborigines for the year 1912. His brief was to advise the government on Aboriginal welfare and administrative matters, but historians have neglected this significant development. It was the first occasion upon which an academic with anthropological expertise (the foremost authority in Australia) was appointed to formulate policy. The government paid all the considerable costs involved. Spencer's report was tabled in parliament in 1913, after a change in government to an administration unsympathetic to his costly recommendations, and only months before the war swept its consideration into oblivion. Although its precepts combined bleak social evolutionary theory with firm paternalism, his recommendations included the creation of several large Aboriginal reserves. If implemented, this policy might have altered the course of Aboriginal history and European settlement. ${ }^{77}$

One important outcome of Spencer's year in the Territory was his Native Tribes of the Northern Territory (1914). This is the classic study of northwestern Arnhem Land. His generalised tribal designation for the Alligator Rivers people, Kakadu, has been perpetuated in the World Heritage property named Kakadu Park. The recognition of Aboriginal bark painting as an art form effectively dates from Spencer's initiative in collecting and donating over 200 bark paintings to the National Museum of Victoria, of which he was the honorary director. His Native Tribes of the Northern Territory illustrated and described examples, the first detailed account of bark paintings. ${ }^{78}$

The recurring theme of ethnographic salvage was reiterated in the same year as Spencer's report to parliament. The 1913 Australasian Association for the Advancement of Science congress resolved: ${ }^{79}$ 'That in view of the rapid decadence and disappearance of the ... aborigines, it is urgent that, in the interests of science, further records and collections ... should be made for public preservation ...'

75

76

77

78

79

Mulvaney \& Calaby 1985 , pp. 189-91.

Eylmann 1908; Courto 1990.

Spencer 1913; Mulvaney \& Calaby 1985, pp. 280-314.

Spencer 1914; Mulvaney \& Calaby, pp. 303-4.

Resolutions of Section F, AAAS 1913, p. 453. 


\section{AUSTRALIAN ANTHROPOLOGY}

Social evolutionary interest in Australia culminated in 1914, when capital cities hosted the British Association for the Advancement of Science meeting. It was a triumph for Baldwin Spencer, one of its organisers. Delegates included his Oxford classmate and Pitt Rivers Museum curator, Henry Balfour, together with R.R. Marett, head of his former college, and Haddon and Rivers, members of the 1898 Cambridge Expedition to Torres Strait. Symbolic of the changing physical and intellectual climate, World War I commenced while the delegates were in Australian waters and Bronislaw Malinowski was aboard the ship, while Radcliffe-Brown attended the congress. ${ }^{80}$ Peterson notes another significant pointer towards change. The British Association meeting resolved to establish a research committee to advance the teaching of anthropology in Australia, but the war intervened. ${ }^{81}$

\section{Professional anthropology}

The saga of the establishment of the Sydney department is well known and is not reviewed here. ${ }^{82}$ As Peterson emphasises, the post-war need to administer the complex region of Papua and the Mandated Territory of New Guinea resulted in an emphasis upon the role of anthropology teaching in training administrators. Ethnographic salvage for social science theory formulation, or to record 'dead' cultures, no longer provided the sole justification for anthropology. Probably the emerging Functionalist anthropology, which stressed indirect rule, appeared more appropriate to New Guinea control than any Australian application, where salvage remained the habitual goal.

This ambivalent role for anthropology in Australia was exemplified at the 1921 AAAS congress, whose president was Spencer. Resolutions included: 83

That there be urged upon the Federal Government the need for endowment of a chair in Anthroppology, especially in view of its value in the government of subject races.

and

That there be ... notice of ... the desirability of at once investigating and recording the Ethnology of the northern part of Western Australia.

The same congress inaugurated the Australian National Research Council (ANRC), which took the lead in promoting the cause of anthropology. Agreement eventuated in 1925 to establish a chair at Sydney, when the Commonwealth and State governments consented to contribute the costs of staff and establishment. They did so in the knowledge that the Rockefeller Foundation had promised a massive injection of research funding.

Peterson, who worked in the Rockefeller New York archives, has described the reasons behind this intervention. It developed from a 1923 request to the Foundation from the eugenicist Galton Society to undertake a major study of 'primitive' societies. ${ }^{84}$ This would have concentrated on the human biology of small-scale societies living under situations where genetic natural selection was operating unhindered by medical intervention. Although this Galton Society proposal was not implemented, the Rockefeller Foundation provided an untied sum, with human biology expected to figure prominently in research projects. Between 1926 and 1938, $£ 52,500$ was granted, an enormous sum in the Depression era.

Previous discussion in this paper indicates that with Radcliffe-Brown's appointment to the chair, the Foundation obtained an anthropological collaborator sympathetic to studies in racial eugenics. Those Rockefeller dollars, together with $£ 3000$ granted in 1940 by the

80 Mulvaney \& Calaby 1985 , pp. 317-18.

81 Peterson 1990.

82 Elkin 1958; Wise 1985; Mulvaney 1988; Peterson 1990.

83 Mulvaney 1988, p. 206.

84 Peterson 1990. 
Carnegie Corporation, constituted almost the total anthropological research component in Australia until after World War 2.

A notable exception was Donald Thomson's Arnhem Land fieldwork in 1935-36, paid for by the Commonwealth government. To that administration, which was lobbied by many interest groups following the deaths of Japanese pearlers and Northern Territory police at the hands of Aborigines, his two expeditions were more in the nature of factfinding or peace-keeping tokens of interest, rather than academic research. This probably explains why the relatively large expenditure of $£ 3175$ was sanctioned. ${ }^{85}$

The Rockefeller funds supported forty-two projects involving thirty researchers or institutions, constituting a virtual honour role of Australasian region anthropologists between the wars. A high proportion of funding was expended in Papua New Guinea, while human biology received a low priority. Those anthropologists whose careers were largely determined or assisted by Rockefeller support included A. Capell, A.P. Elkin, R. Fortune, C. Hart, I. Hogbin, P. Kaberry, U. McConnel, R. Piddington, S.D. Porteus, H. Powdermaker, A. Radcliffe-Brown, L. Sharp, W. Stanner, T. Strehlow, D. Thomson, L. Warner and C. Wedgewood. What biological research was achieved largely involved initiatives by the South Australian Board for Anthropological Research, rather than by grantees centred on Radcliffe- Brown's (later Elkin's) department. 86

It is ironic that Australian cultural life was so moribund in the thirties, and British concern for its Dominion's cultural well-being so slight, that it was the Carnegie Corporation of New York which sponsored an investigation of Australia's decaying moveable cultural relics. The recommendations of the critical Report on the Museums and Art Galleries of Australia were ignored by all authorities, then in the forced parsimony of the Depression. 87

The Foundations continued into post-war Australia as significant patrons of anthropology. Except for the establishment by the Commonwealth government of the Research School of Pacific Studies at the new Australian National University, which embraced research in anthropology, and its recognition of post-war obligations in the South Pacific by funding the training of administrative officers at the Sydney-based Australian School of Pacific Administration, government priorities lay elsewhere. The Carnegie Corporation continued its positive role, when it funded the initial three years of the subdepartment of Anthropology, at the University of Western Australia, from 1955. This soon developed into Australia's second teaching department of anthropology. Between 1956 and 1958, Carnegie funds also funded two research projects, totalling $£ 1800$.

For a few years from the late fifties, the Nuffield Foundation supported archaeological research, the grants amounting to several thousand pounds. Most significantly, it was support from the Myer Foundation and the Myer Charity Trust, totalling $\$ 78,000$ that, in 1964, initiated the landmark 'Aborigines in Australian Society Project' of the Academy of the Social Sciences in Australia. The series of ensuing publications, especially Charles Rowley's three distinguished volumes of 1970 , played a crucial role in the early seventies in alerting non-Aboriginal Australians to Aboriginal deprivation and needs. It also directed historians to the neglected field of Aboriginal history since 1788.

\section{The Rockefeller Foundation}

It is evident that the philanthropic Foundations have exerted a profound influence on the growth of Australian anthropological investigation and social knowledge. In a series of

85 Peterson 1983, p. 9.

86 Mulvaney 1988 , pp. 209-11.

87 Markham and Richards 1933. 


\section{AUSTRALIAN ANTHROPOLOGY}

critical though repetitious papers, Donald Fisher argues that the subtle 'gatekeeper' functions assumed by the Rockefeller Foundation in particular, have blurred the distinction between academic and intellectual independence on the one hand, and the control of avenues of research and teaching on the other. ${ }^{88}$ Fisher argues that the establishment and dominance of functionalist/structure-function anthropology during the inter-war period in the British Commonwealth was assured only because Rockefeller intellectual concerns and finance proved critical. Because Foundation objectives to promote increased efficiency coincided with the 'functional view (which) involved the search for definite laws of social process', Fisher concluded, 89 it implied 'an ideological convergence between the tenets of Social Anthropology and the objectives of Rockefeller philanthropy'.

The extent to which such sweeping and cynical claims are valid, may be evaluated by considering some aspects of Foundation relations with the Sydney department. A case study of the treatment of Ralph Piddington, a departmental graduate and a Rockefeller Fellow is particularly relevant. Before examining that case, however, it is emphasised that, in opposition to Fisher's thesis, the Australian National Research Council files reveal its complete freedom of action from Foundation pressure. The ANRC, advised by an anthropological committee chaired by Radcliffe-Brown (later by A.P. Elkin), administered Rockefeller funds. The only note of censure in correspondence arose when Radcliffe-Brown attempted to act executively without reference to the ANRC. ${ }^{90}$ Although so few grants concerned human biology, the original prime purpose of Rockefeller initiative, no reference to this neglect or any rebuke was received from New York.

It is relevant to note Foundation reaction to an ANRC. emergency, when the ANRC Treasurer committed suicide in 1934, after embezzling funds. Fortunately for anthropology, Rockefeller money remained intact, unlike $£ 5000$ misappropriated from the Carnegie Corporation. Even so, this episode revealed laxity and unprofessional administration. Instead of criticism, the Foundation advanced $£ 700$ in case it was needed in the emergency, and proceeded to unconditionally allocate its funding for the next three years. ${ }^{91}$

On the occasion of the expiry of its funding agreement in 1938, the Foundation sought ANRC reflections on the success of the programme. ${ }^{92}$ 'We are interested in knowing whether our assistance has led to the recognition of the importance of continuing activity and if local financing will be sufficient to maintain it', its Director observed.

Although the response to the second query was not encouraging, the Foundation's note of acceptance was both courteous and understanding, with no indication of disappointment, irritation or warning for lost opportunities, past or future:

It is evident from the record that there was notable achievement in the direction of the two objectives of the Foundation grants ... The Department of Anthropology has certainly become established ... and there is at least a fair prospect of continuance of a limited amount of research in the Western Pacific.

\section{Ralph Piddington and the Rockefeller Foundation}

Ralph O'Reilly Piddington (1906-74) graduated from Radcliffe-Brown's Sydney department. After completing his Master's degree he was awarded a Rockefeller Fellowship by the ANRC to work amongst the Aborigines in the Broome area of northwestern

88 Fisher 1980a, b; 1983; 1986.

89 Fisher 1980a; 1986, p. 5-8.

90 ANRC papers, NLA, MS 482, box 61/855, 24 July 1930.

91 G.A. Julius to E.E. Day, 26 June 1934; S.H. Walker to Julius, 10 Oct 1934 (NLA MS 482, box 23/328).

92

Walker to A.B. Walkom, 10 Mar, 12 July 1938 (ibid). 


\section{ABORIGINAL HISTORY 1993 17:2}

Australia. He completed two fieldwork seasons during 1930 and 1931, for which the quality of his research was commended by senior anthropologists. On 14 January 1932, the Sydney newspaper, The World, published an interview with Piddington, under the headline 'Aborigines on cattle stations are in slavery'. In his stinging attack, Piddington cited specific instances of gross racial discrimination and urged a government inquiry into the conditions of Aborigines across northern Australia. These accusations were reported in the overseas press and excited some interest amongst humanitarian welfare organisations.

In the same newspaper, on 7 July 1932, Piddington published a signed column-length article, detailing actions by police and pastoralists and labelling the Western Australian government as 'callously indifferent', that State as a 'plague spot of European oppression', and the affair 'a national disgrace'. With the knowledge of hindsight of Kimberley racial history and of the details which Piddington later supplied to the ANRC in his defence, there is little doubt that he spoke the truth, tinged perhaps with the rash emotionalism of youth.

Whatever the merits of his claims, the wrath of the Western Australian Chief Protector of Aborigines, A.O. Neville, was visited upon him, via the ANRC. Neville was in an ideal position to complain, because he was a member of the ANRC anthropology committee on Rockefeller funding awards. Piddington was in London by the time of Neville's delayed accusations. Raymond Firth, as acting-head of Sydney's anthropology department (following Radcliffe-Brown's translation to Chicago), wrote sternly to Piddington on 8 September 1932.93

The matter is serious, especially since Mr Neville informs me that you would not be welcome should you think of returning ... for further work, and any other anthropologist will be asked in future to give an assurance that he will not make statements reflecting against the administration without first giving the administration an opportunity of refuting or investigating these charges.

Piddington delayed his sturdy and detailed response until 17 July 1933, because he wished to discuss matters in person with Firth, who was going to London in 1933 . He detailed incidents and individuals behind his general newspaper denunciation, emphasising that his attack was not directed upon Neville's under- funded Department of Aborigines, but 'upon the general attitude of white people to Aborigines'; besides, he had informed Neville of many injustices previously, and in person.

This did not satisfy the ANRC council, whose secretary, A.J. Gibson, informed Piddington on 23 December 1933, that 'failing a satisfactory explanation', further funding would be terminated. It must be inferred from a previous letter from Gibson to A.P. Elkin, Firth's successor as chairman of the anthropology advisory committee, that Elkin agreed with this action. By that date, also, the Western Australian department belatedly furnished the ANRC council with its slate of accusations concerning Piddington's behaviour in the field.

This dossier had been assembled from reports by local officials and makes intolerant reading today. ${ }^{94}$ Piddington was observed to drive female Aborigines in his vehicle; he was seen to transport liquor; he was 'said to be addicted to drink'; he took informants away without consulting authorities; his conduct was 'hardly in keeping with the position he held'. Generally the tenor of those accusations was petty. For any Broome resident of those times to criticise alcohol consumption was sheer hypocrisy. It also revealed complete ignorance of the nature of anthropological fieldwork, while incidentally illuminating local

93 ANRC papers, NLA, MS 482, box 61/859A. Unless otherwise stated, all documents relating to Piddington are included in this file.

94 Various documents are in ANRC box 61/589A, together with other material in MS 482, boxes $22 / 300$ and $45 / 762$. 


\section{AUSTRALIAN ANTHROPOLOGY}

racial attitudes towards Aboriginal people. One witness even seemed critical that Piddington travelled with his wife. However, his most heinous offence, commented on by two officials; was Piddington's presence in Broome 'at a convivial evening when the Red Flag and Communist songs were sung'.

On 23 December 1933, Gibson also wrote to E.E. Day, at New York Rockefeller Foundation headquarters, informing him in more temperate terms than his letter of that day to Piddington, of the intended withdrawal of support by the ANRC (As the ANRC previously had commended Piddington's two field seasons to the Foundation, Gibson needed to be diplomatic.)

If Fisher's thesis is valid, that the Rockefeller Foundation subtly promoted conservative, capitalist values, the ANRC termination of Piddington's support should have been commended. The reverse is the case. On 31 January 1934, S. May, Assistant-Director of the Rockefeller Foundation, wrote a lengthy letter to A.J. Gibson, with a copy to Piddington.

May observed sagely that they were concerned with the charges against Piddington for several reasons. In the first place, he had been praised by experts for the quality of his research and there had been a considerable investment in the expectation of his succeeding in a professional career. As Piddington had made public criticisms concerning the treatment of Aborigines, "there would seem to be a reasonable doubt of the objectivity of those who prefer the charges against him, since they would appear to be officials who might have been irked by ... criticism'. Those accusations were levelled only months after Piddington's newspaper articles, and claims of drunkenness rested upon 'hearsay'. As for the Red Flag, 'it would not seem to us that the fact that Mr Piddington was heard to have sung Communist songs with a group of friends was conclusive evidence that he is a Communist; but, in any event, the Foundation does not inquire into political opinions of fellowship applicants'. In the opinion of the Foundation, therefore, the charges 'would not constitute a valid ground' for terminating Piddington's fellowship. Therefore May suggested that the ANRC consider the matter further, in the light of Piddington's response to the accusations.

Although the ANRC and its anthropological advisors remained unforgiving, they were thrown into confusion when, on 24 May 1934, Piddington wrote refuting the accusations and notifying his wish to resume fieldwork. The file contains a lengthy exchange of letters between officials and the Foundation, seeking some alternative arrangement, such as Piddington remaining in England. Gibson informed May on 4 July 1934, that the ANRC was adamant that Piddington could not return to Western Australia, because 'it is not possible to ignore the representation of an official of Mr Neville's standing', who also sat on their advisory committee.

How valuable was Neville's opinion? He was a dedicated but overworked public servant, not an anthropologist. ${ }^{95}$ Like many later Aboriginal affairs administrators, he was prone to take attacks on government policy as personal criticism, and he probably felt jealous of the opportunities afforded young researchers unavailable to himself. Neville's stated mission was to 'breed-out' the black population. ${ }^{96}$ Miscegenation was the ultimate solution, he proclaimed, believing that 'atavism is not in evidence so far as colour is concerned. Eliminate in future the full-blood and the white and one blend will remain ... the race will become white'. An eastern Aboriginal leader described the policy of his department as 'out Hitlering Hitler'.97 The extent of his authoritarian eugenic scientism

95 Jacobs 1986

96 ibid, pp.16-17.

97 Hall 1989 , p. 24 
was expounded at length some years later in his book Australia's Coloured Minority. 'The native must be helped in spite of himself!', Neville announced, ${ }^{98}$ 'Even if a measure of discipline is necessary it must be applied, but it can be applied in such a way as to appear to be gentle persuasion ... the end in view will justify the means employed'.

ANRC secretary Gibson already had revealed his prejudices on 16 May 1934, in a letter to Professor D. Copland, Rockefeller Fellowships Adviser in Australia. He drew attention to an item in Mr and Mrs Piddington's Perth hotel expenses during a week's stay in 1931. At the time Piddington had submitted that account, he stated that he did not expect such personal items to be charges against his grant. Notwithstanding, Gibson primly observed with hindsight, that the 'liquors' account for $£ 5 / 13 / 3$, 'seems to lend some colour to the charges' of excessive drinking in Broome.

Copland obviously felt uncomfortable as the intermediary and requested that the entire Piddington file be sent to him. He reported on 3 September that he had heard that Piddington was 'discouraged' and felt that it was pointless to return to certain unemployment. Copland hinted that he hoped for some compromise advice which he could present to the Foundation, offering a 'view of the situation rather more favourable' to Piddington.

The file was then handed to Elkin for advice, as chairman of the anthropology committee. Elkin's counsel was both expedient and intellectually authoritarian. Having read the correspondence, Elkin concluded on 18 September 1934, 'and it may be that, for the sake of the Rockefeller Foundation ... we should give Piddington a grant ...' He then stated the terms. Any return to Western Australia was impossible, even though Piddington had offered to submit any criticisms to Neville before their publication-'after all, we have to consider Neville who has helped us considerably with research work in Western Australia'. (The 'us' in this case probably should have read 'me', because Elkin had established friendly contact with Neville since his own 1928 Kimberley research). Elkin suggested sending Piddington somewhere else in northern Australia, but only if he studied social anthropology. Here Elkin's prejudices showed. He had heard that in England, Piddington's 'interest had been transferred to an aspect of Psychology. I, personally, could not recommend that a field worker should be sent to do Psychology, for I do not think that the expenses involved in Professor Porteus' expedition and Piddington's second expedition were justified'. (S.D. Porteus worked under Rockefeller auspices in 1929. Before Piddington's second expedition he spent some time in Porteus' department at the University of Hawaii, studying racial psychology.)

Less inflexible than Elkin's committee, and concerned for Piddington's welfare, the Rockefeller Foundation finally abandoned Piddington's Australian cause and arranged for him to remain in London and to prepare for fieldwork in Africa. When conveying this welcome news to Gibson on 19 November 1934, almost three years after Piddington's offending newspaper interview, Copland reminded the ANRC that such eminent authorities as Malinowski, Firth, Seligman and Westermann all expressed 'entire satisfaction' with Piddington's research. Indeed, he remained in their London School of Economics, completing his doctorate in 1938. Undeterred, by Copland's implicit rebuke, Gibson responded by thanking Copland on 10 December, because his news 'relieves my Executive of a good deal of worry ... by the departure of Piddington for fresh fields, in a new continent'.

Except for service during World War II, Piddington only returned to his native land in 1967, when he revisited his former research area, on a grant from the Australian Institute of 


\section{AUSTRALIAN ANTHROPOLOGY}

Aboriginal Studies. In retrospect, his treatment appears as possibly the first of several blatant denials of academic (and civil) freedom to anthropologists. Other important but unstudied cases meriting investigation concern Donald Thomson's exclusion from Cape York, apparently at the instigation of missionary authorities during the fifties, and the Commonwealth administration's refusal to permit Fred Rose to enter Arnhem Land a decade later. Each case has involved a government instrumentally acting in concert with the often sympathetic collaboration of the relevant timid or politicised academic establishment. In this instance the Rockefeller Foundation showed tolerance, generosity and restraint, while the Australian administrators of Foundation largesse based their case on hearsay and the influence of a self-interested public servant, placing academic considerations on the lowest level.

As the newly appointed head of Australia's only anthropology department, A.P. Elkin revealed himself to be an adviser whose concept of anthropology was narrowly defined and who was willing to be guided by expediency. Just as he eliminated psychological anthropology from the 'true way' of social anthropology (and continued to do so), he also treated research by South Australians on various biological and material culture fields with a dismissive and unhelpful approach. 99 From the author's experience of conditions and researchers during the forties and fifties, it is evident that Elkin frequently hindered research by any but those in, or from, his own department.

Such possibly uncharitable observations explain, to some extent, the slow growth of anthropology in other centres. They neither explain the cultural apathy which characterised white Australian attitudes to the indigenous people, nor excuse the harsh paternalist and Eurocentric policies adopted by State and Federal Aboriginal 'welfare' bureaucracies during this same stark period.

\section{To the present}

Anthropology in Australia originated with the dedication and financial sacrifices of a few persons imbued with the urgency of salvaging past evidence for the future. The development of significant fieldwork in Australia and New Guinea between the wars was the consequence of Rockefeller benefaction. Through the forties to the sixties, substantial contributions flowed from the Carnegie Corporation and the Nuffield Foundation. It is evident that research until the sixties resulted from American and some British capital. Only in the sixties did local Foundations capital provide some funding. Government contributions to genuine anthropological research proved rare indeed. It is worth noting that while the Commonwealth government appointed two staff anthropologists to the Papua New Guinean administration between the wars, no comparable appointments occurred in Australia. There was one exception, when E.W.P. Chinnery, a former New Guinea government anthropologist, was appointed Director of Native Affairs in the Northern Territory in mid-1939. The potential of that appointment was unrealised, as the outbreak of war followed and swept aside any good intentions. It is evident that State administrations variously appointed Commissioners or Directors of Native Affairs, or Chief Protectors of Aborigines. Such titles disguise, however, the reality that such officials simply were public servants appointed to implement policy. Their departments did not undertake independent research into cultural matters, economic needs or social means. Frequently they were ignorant of anthropology, and were unsympathetic to the problems of Aboriginal culture and were untrained to cope with special requirements. 
The critical change in Australian attitudes belongs to the late 1950's, probably associated with the booming economy and expanding population. The Murray Commission into university needs resulted in a massive expansion of universities from seven to nineteen in about fifteen years from 1960. Some of these institutions adopted anthropology as a priority for teaching. The decade from 1957, when the author introduced the first teaching of Oceanic and Australian prehistory in a university, witnessed some 25,000 years added to Australia's human past by archaeologists, and the growth of environmental, and ecological studies in relation to human settlement. Australian and Melanesian discoveries today place this region in the forefront of the global history of Homo sapiens.

In 1959, a Liberal Party member of the House of Representatives, W.C. Wentworth, proposed the creation of an Australian Institute of Aboriginal Studies. Like Howitt seventy years before him, Wentworth stressed the theme of urgent salvage. The Act establishing the AIAS in 1964 represents a cultural benchmark, because its budget supported comprehensive research across a broad spectrum. 100 Only since then, have major projects resumed on a scale surpassing the Rockefeller programme over thirty years previously. Between 1965 and 1975 every State enacted (although inadequately implemented) legislation to protect Aboriginal sites and relics.

More significant, however, was the growth of Aboriginality from the late sixties. This is a fundamental cultural revival and identity search, so that by the end of this century Aboriginal anthropologists should be undertaking their own major research. The challenge to all governments and to both Aboriginal and non-Aboriginal Australians, is to ensure that research and teaching funding in anthropology is adequate, and it is undertaken in an ambient cultural environment in which the urgency of salvage and the rivalry of selfinterest are no longer the motivating forces, where interracial harmony and mutual respect have replaced them.

\section{LIST OF REFERENCES}

Australasian Association for the Advancement of Science 1913, 'Section F, Reports of Research Committees', Australasian Association for the Advancement of Science Reports of Meetings, vol. 14, pp. 448-53.

Australian National Research Council, Papers, National Library of Australia, Canberra.

Barnard, J. 1890, 'The Aborigines of Tasmania', Australasian Association for the Advancement of Science Reports of Meetings, vol. 2, pp. 597-611.

Bleek, W.H.I. 1874, 'On inquiries into Australian Aboriginal folklore', The Cape Monthly Magazine, 9, pp. 129-36.

Cooper, C. 1990, Aboriginal and Torres Strait Islander Collections in Overseas Museums, Canberra.

Courto, V. 1990, The tragical history of Dr Eylmann, unpublished BA Honours thesis, Department of Archaeology and Anthropology, Australian National University, Canberra.

Crawley, A.E. 1902, The Mystic Rose: A Study of Primitive Marriage. New York.

Cur, E.M. 1886, The Australian Race, 4 vols. Melboume.

Durkheim, E. 1912, Les Formes élémentaires de la Vie religieuse, Paris.

Elkin, A.P. 1958, 'Anthropology in Australia: One chapter', Mankind, vol. 5, pp. 225-42.

1975-6, 'R.H. Mathews: His contribution to Aboriginal studies', Oceania, vol. 46 pp. 1 24, pp. 126-52, pp. 206-34.

Eylmann, E. 1908, Die Eingeborenen der Kolonie Südaustralien, Berlin.

Eyre, E.J. 1845, Journals of Expeditions of Discovery, 2 vols. London.

100 Mulvaney 1986. 


\section{AUSTRALIAN ANTHROPOLOGY}

Fisher, D. 1980a, 'American philanthropy and the social sciences in Britain 1919-39, the reproduction of a conservative ideology', Sociological Review, vol. 28, pp. 277-315.

$1980 \mathrm{~b}$, American philanthropy and the social sciences: the reproduction of a conservative ideology' in Philanthropy and Cultural Imperialism, ed. R.F. Arnove, Boston. 1983, The role of philanthropic foundations in the reproduction and production of hegemony', Sociology, vol. 17, pp. 206-33.

1986, 'Rockefeller philanthropy and the rise of social anthropology', Anthropology Today, vol. 2, no. 1, pp. 5-8.

Fison Papers, National Library of Australia, MS 7080, Canberra.

Frazer, J.G. 1899, 'Observations on Central Australian Totemism', Journal of the Anthropological Institute, vol. 28, pp. 281-6.

Freud, S. 1913, Totem and Taboo, London.

Grey, G. 1838, 'A brief outline of a recent expedition to the North West coast of Australia', Joumal of the Royal Geographical Society, vol. 8, pp. 459-460.

1841 , Journals of Two Expeditions of Discovery, 2 vols, London.

Hall, R.A. 1989, Black Diggers. Sydney.

Hartland, E.S. 1909, Primitive Paternity,. London.

Howitt, A.W. 1889, 'On the organisation of the Australian tribes', Proceedings of the Royal Society of Victoria, vol. 1, pp. 96-137.

1891, 'Anthropology in Australia' Proceedings of the Royal Society of Victoria, vol. 3, pp. $15-22$.

Jacobs, P. 1986, 'Science and veiled assumptions: Miscegenation in W.A. 1930-1937', Australian Aboriginal Studies, no. 2, pp. 15-23.

Jenks, E. 1895, A History of the Australasian Colonies, London.

Jones, P.G. 1987, 'South Australian anthropological history: The Board for Anthropological Research and its early expeditions', Records of the South Australian Museum, vol. 20, pp. 71-92.

Jones, P. \& Sutton, P. 1986, Art and Land, Adelaide.

Lang, A. 1903, Social Origins, London. 1905, The Secret of the Totem, London.

Malinowski, B. 1913, The Family among the Australian Aborigines, London.

Markham, S.F. \& Richards, H.C. 1933, A report on the Museums and Art Galleries of Australia, London.

Marett, R.R. 1909, The Threshold of Religion, London.

Mulvaney, D.J. 1958, 'The Australian Aborigines, 1606-1929: Opinion and fieldwork', Historical Studies, vol. 8, pp. 131-51, pp. 297-315. 1970, 'The anthropologist as tribal elder', Mankind, vol. 7, pp. 205-17.

1971, 'The ascent of Aboriginal man: Howitt as anthropologist', in Come Wind, Come Weather, M.H. Walker, Melbourne pp. 285-324.

1987, 'Gum leaves on the Golden Bough: Australia's Palaeolithic survivals discovered', in Antiquity and Man J.D. Evans et al, London, pp. 52-64.

1986, " "A sense of making history": Australian Aboriginal Studies 1961-1986', Australian Aboriginal Studies, no. 1, pp. 84-57.

1982, 'Patron and client: the web of intellectual kinship in Australian anthropology', in Scientific Colonialism: A Cross-Cultural Comparison, eds N. Reingold \& M. Rothenberg, Washington.

1988, 'Australian anthropology and ANZAAS', in The Commonwealth of Science, ed. R.

McLeod, Melbourne, pp. 196-221.

1989a, Encounters in place: Outsiders and Aboriginal Australian 1606-1985, St. Lucia, Qld.

1989b, 'Reflections on the Murray Black Collection', Australian Natural History, vol. 23, pp. 66-73.

\& Calaby, J.H. 1985, 'So Much that is New' Baldwin Spencer 1860-1929, Melbourne.

Myers, C.S. (ed.) 1906, The Evolution of Culture, Oxford. 


\section{ABORIGINAL HISTORY $1993 \quad$ 17:2}

Neville, A.O. 1947, Australia's Coloured Minority: Its Place in the Community, Sydney.

Peterson, N. 1983, Donald Thomson in Arnhem Land, South Yarra, Vic. 1990, 'The history of the institutionalisation of Aboriginal anthropology', Australian

Aboriginal Studies, no. 2, pp. 3-19.

Radcliffe-Brown, A.R. 1930, 'Applied anthropology', Report of ANZAA.S 20, pp. 267-80.

Roth, W.E. 1897, Ethnological Studies among the North-West-Central Queensland Aborigines, Brisbane.

1901-1910, North Queensland Ethnography Bulletin, 1-14.

Rowley, C.D. 1907 a, Outcasts in White Australia, Canberra. The Remote Aborigines, Canberra.

Smyth, R.B. 1878, The Aborigines of Victoria, 2 vols., Melbourne.

Spencer, W.B. 1901, Guide to the Australian Ethnographical Collection in the National Museum of Victoria, Melboume.

1913, 'Preliminary report on the Aboriginals of the Northern Territory', Bulletin of the

Northern Territory, no. 76, Department of External Affairs, Melbourne. 1914, The Native Tribes of the Northern Territory, London.

Taplin, G. 1874, The Narrinyeri ... Adelaide.

1879, Folklore, Manners, Customs and Languages of the South Australian Aborigines, Adelaide.

Thomas, N.W. 1906, Kinship Organisations and Group Marriage in Australia, Cambridge.

Tippet collection, St Marks National Theological Centre, Canberra - Fison papers.

Tylor, E.B. 1893, 'On the Tasmanians as representatives of Palaeolithic man', Journal of the Anthropological Institute, vol. 23, pp. 141-52.

Van Gennep, A. 1906, Mythes et Legéndes d'Australie: Études d'Ethnographe de Sociologie, Paris. 1909, Les Rites de Passage, Paris.

Victoria, Parliament, Legislative Council 1859, Report of the Select Committee on the Aborigines, Govt pr, Melboume.

Victoria, Royal Commission on the Aborigines 1877, Report of the Commissioners to Enquire into the present Condition of the Aborigines of the Colony ... Govt pr, Melbourne.

Wake, C.S. 1872, The mental characteristics of primitive man, as exemplified by the Australian Aborigines, Journal of the Anthropological Institute, vol. 1, pp. 74-84. 1889, The Development of Marriage and Kinship, London.

Warner, W.L., Radcliffe-Brown \& Burton, F.W. 1928, 'Some aspects of the Aboriginal problem in Australia', The Australian Geographer, vol. 1, pp. 67-9.

Westermarck, E. 1906. The Origin and Development of the Moral Ideas, 2 vols., London.

Wise, T. 1985, The Self-made Anthropologist, Sydney. 